\title{
IS SUSTAINABLE DEVELOPMENT AN ISSUE FOR QUALITY MANAGEMENT?
}

\section{Małgorzata JASIULEWICZ-KACZMAREK}

Poznan University of Technology, Faculty of Engineering Management, Poznań, Poland e-mail: malgorzata.jasiulewicz-kaczmarek@put.poznan.pl

\begin{abstract}
In recent years, sustainable development strategy for enterprises has become an important issue around the globe. This requires the organization to review its current systems to improve the overall triple bottom-line performance (i.e. economic, environmental, and social). Rising to these challenges requires transforming management system towards sustainable management. Assuming quality management (QM) impact on organisations will continue, what types of QM-based improvement initiatives will develop in the future to meet the anticipated organizational and market changes?
\end{abstract}

Keywords: sustainable devepolment, quality management, sustainable quality management, customer, stakeholders.

\section{Introduction}

Since the end of the 1980s, as a result of the report "Our common future" published by the World Commission on Environment and Development, politics, economy, and science have been dominated by the term "sustainable development" (SD). In the report, SD was defined as a process of change in which exploitation of resources, new investments, concentration on technology development, and institutional changes are focused on present and future needs of society. At the macro level, a model of economy based on the concept of SD assumes appropriate and conscious forming of relations between economic growth (economic aspect), commitment to environment (environmental aspect), and quality of life (social aspect). For a company (micro level), SD means adoption of such business strategy and such actions that contribute to satisfying present needs of company and its stakeholders, as well as simultaneous protection, maintenance, and strengthening of human and environmental potential that will be needed in the future [68].

These new challenges are accompanied with a growing focus on the role of the quality management (QM) approach. The question then arises: is SD an issue for QM? As is well-known, the framework of quality has constantly evolved in accordance with environmental changes, and due to the absorbing and adaptable capability, the quality approach has "received" many new names.

This paper aims to address the issue of QM in today's turbulent environment. To answer the question asked in the title of the this paper, the paper is structured as follows. In the second chapter, the idea of SD is characterized. The term "sustainable development" is defined, challenges of the approach are introduced, both at the global and operational level, and strategies for the integration of SD into business processes are presented. In the third chapter, the idea of QM is characterized. Evolution in approach to QM is discussed and features characterizing each stage of QM development are listed. In the fourth chapter, common elements of both approaches: SD and QM are identified and analyzed to define issues of SD referring to QM. The new stage of QM development was called Sustainable Quality Management, as it increases the range of isuues that should be considered when shaping QM system in a company. Sustainable quality management provides a potential to improve and extend the theory generation and the best practices of QM in the future. The fifth chapter is a summary. The important area of the research conducted is analysis of range of sustainable management practices reaching beyond an organziation.

\section{Sustainable development}

\subsection{SD definition and issues}

The origin of the English word sustain is in the Latin words sub (under, from below), and tenere (to hold, to hold up). To sustain, then, means to keep up, to maintain, to support, to prevent from sinking or falling something. Sustainability is the ability to maintain or support an activity or process over the long term [10]. In the context of human development and environmental stewardship, the term sustainability has ideological, political, ecological, and economic contexts and, in this framework, it is most commonly seen as a derivation of the term $\operatorname{SD}[62,12]$. 


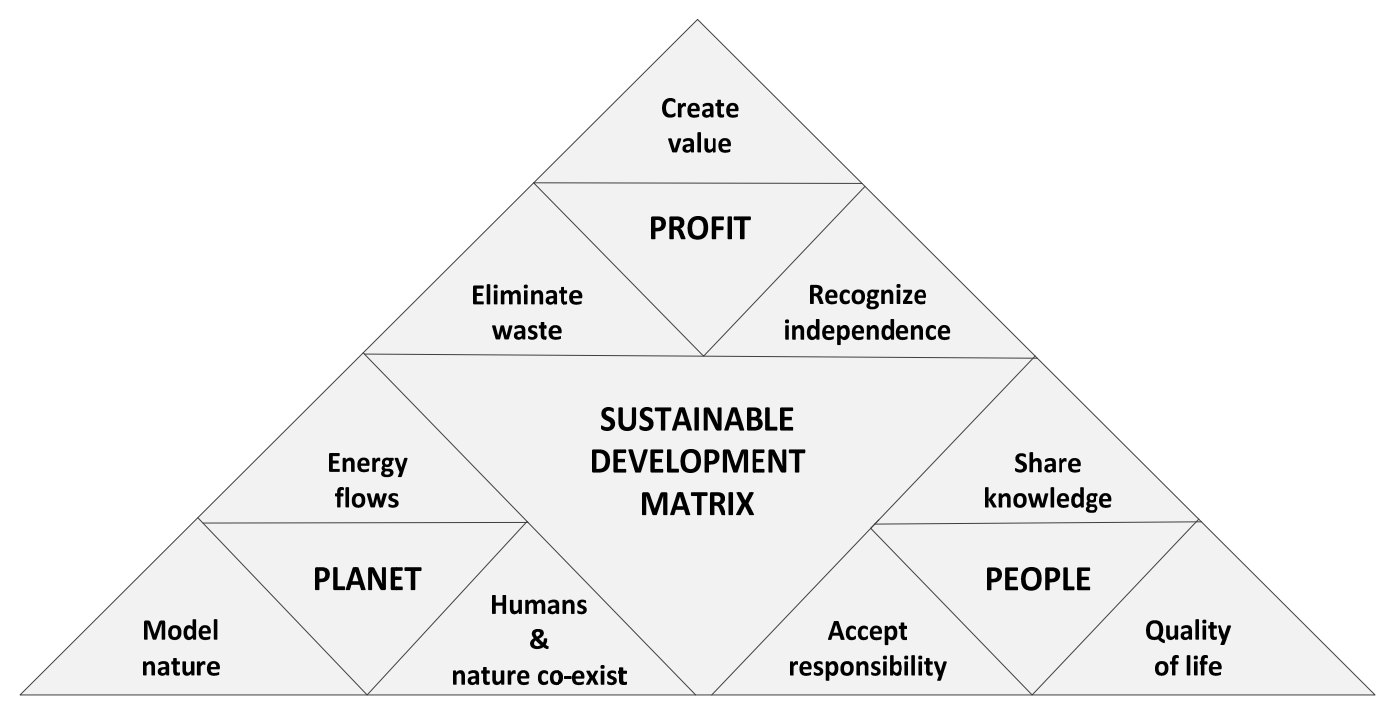

Figure 1. 3P's model (source: [52])

The term SD has different meanings to different people and has numerous interpretations. One of first and most cited definitions of sustainability was created in 1987 by the Brundtland Commission, which defined SD as development that "meets the needs of the present without compromising the ability of future generations to meet their own needs" (...) "Sustainable development is not a fixed state of harmony, but rather a process of change in which the exploitation of resources, the direction of investments, the orientation of technological development, and institutional change are made consistent with future as well as present needs" [75]. Thus, SD is about reaching a balance between economic, social, and environmental goals, as well as people's participation in the planning process in order to gain their input and support [69]. Sometimes SD is referred to as a triangular theory, reflecting the triple bottom line: social, environmental, and economic criteria; terms like; 3P's - people, planet and profit (see Fig. 1) or even 3E's - equity, environment, and economy [77].

Szekely and Knirsch [73] defined sustainability as creating a proper balance between economic, social, and ecological aims. They believe that for businesses, this includes sustaining and expanding economic growth, shareholder value, prestige, corporate reputation, customer relationships, and the quality of products and services. By Robert W. Kates et al. [41], SD is defined through goals, indicators, values, and practice. The British Standard on sustainability management defined SD as "an enduring, balanced approach to economic activity, environmental responsibility, and social progress" [9]. This definition makes two fundamental points: first, that SD necessarily considers social, eco- nomic, and environmental aspects together, and second, that options for the future should not be limited. An important practical implication of this is that tackling any of these issues in isolation can result in unintended consequences along other dimensions. Decisions must be taken in a way that integrates all these concerns, and this means taking into account the concerns of stakeholders from outside the organization as well as within it.

Analysis of the definitions presented above leads to the conclusion that SD requires:

- a broad view of social, environmental, and economic outcomes;

- a long-term perspective, concerned with the interests and rights of future generations as well as of people today;

- an inclusive approach to action, which recognizes the need for all people to be involved in the decisions that affect their lives.

$\mathrm{SD}$ is a process on the way to a crucially important goal: sustainability. Achieving sustainability requires supporting action from all sectors of society, including business.

\subsection{Corporate sustainability}

SD requires the contribution and involvement of many actors. Companies are important players, as they influence the natural environment and society with their product designs and offers, their production processes, purchasing decisions, and their business models [18]. 
SD therefore requires companies to get actively involved in shaping and implementing sustainability measures. The objective of SD confronts business enterprises with three sustainability challenges [66]:

- ecological challenge: increasing ecological effectiveness,

- social challenge: increasing social effectiveness,

- economic challenge to environmental and social management: improving eco-efficiency and/or social efficiency.

Enterprises must manage all these conflicting aspects of sustainability in an integrated manner, focusing not only on environmental or social performances, but also on sustainability of business.

And what does the term "sustainability" mean for an enterprise? According to Grudzewski and Hejduk [25], Sustainability is the capability of an enterprise to continuously learn, adapt and develop, revitalize, reconstruct, and reorient for maintaining solid and distinctive position in a market by offering extraordinary value for buyers, today and in the future (according to paradigm of innovative growth), thanks to organic changeability constituting business models and emerging from creating new opportunities and goals, as well as answering to them, with balancing interests of various groups. (...) Sustainability is based on the following principles: holistic, and continuously developing view of reality, reflections, cooperation, openness to changes, learning, and trust". According to SidorczukPietraszko [68], for a company SD means adoption of such business strategy and such actions that contribute to satisfying present needs of the company and interested parties, as well as simultaneous protection, maintenance, and strengthening of human and environmental potential, which will be needed in the future. Zairi [76], defined sustainability as the ability of an organization to adopt to change in the business environment to capture contemporary best practice methods and to achieve and maintain superior competitive performance.

Pojasek [57] believes that the problem with these definitions is that it is difficult to make operational. To help people understand how to put sustainability to work, he would propose the following as a starting point for creating a definition: "Sustainability is the capability of an organization to transparently manage its responsibilities for environmental stewardship, social well-being, and economic prosperity over the long term while being held accountable to its stakeholders" [57]. This definition of sustainability requires each organization to act responsibly. So it is up to the organization to determine what constitutes responsible behavior, and then manage its actions so that the responsibilities are practiced.

As SD has become the basic factor of competitiveness for many manufacturing enterprises worldwide $[20,36$, $26]$, the need exists to operationalize the approach. Hence, the question arises: how to integrate SD into business processes and everyday routines?

A number of authors have discussed the strategies for the integration of SD into business processes. Review of literature on the subject provides recognition of the three groups of strategies:

- approach based on international and national standards,

- approach based on business excellence models, and

- other approaches, benefiting from various elements of various management ideas.

The first group includes approaches based on standards developed by International Standardization Organization (ISO) $[13,56,27]$. The ISO has developed a number of standards related to the management of SD. The standards most often presented in the literature are:

- ISO 26000:2010 "Guidance on social responsibility", which provides guidance on how businesses and organizations can operate in a socially responsible way, it is a guidance rather than requirements, so it cannot be certified to unlike some other wellknown ISO standards,

- ISO 20121:2012 "Event sustainability management systems Requirements with guidance for use", which provides the framework for identifying the potentially negative social, economic and environmental impacts of events by removing or reducing them, and capitalizing on more positive impacts through improved planning and processes,

- ISO 14001:2004 "Environmental management systems Requirements with guidance for use", which provides practical tools for companies and organizations looking to identify and control their environmental impact and constantly improve their environmental performance. 


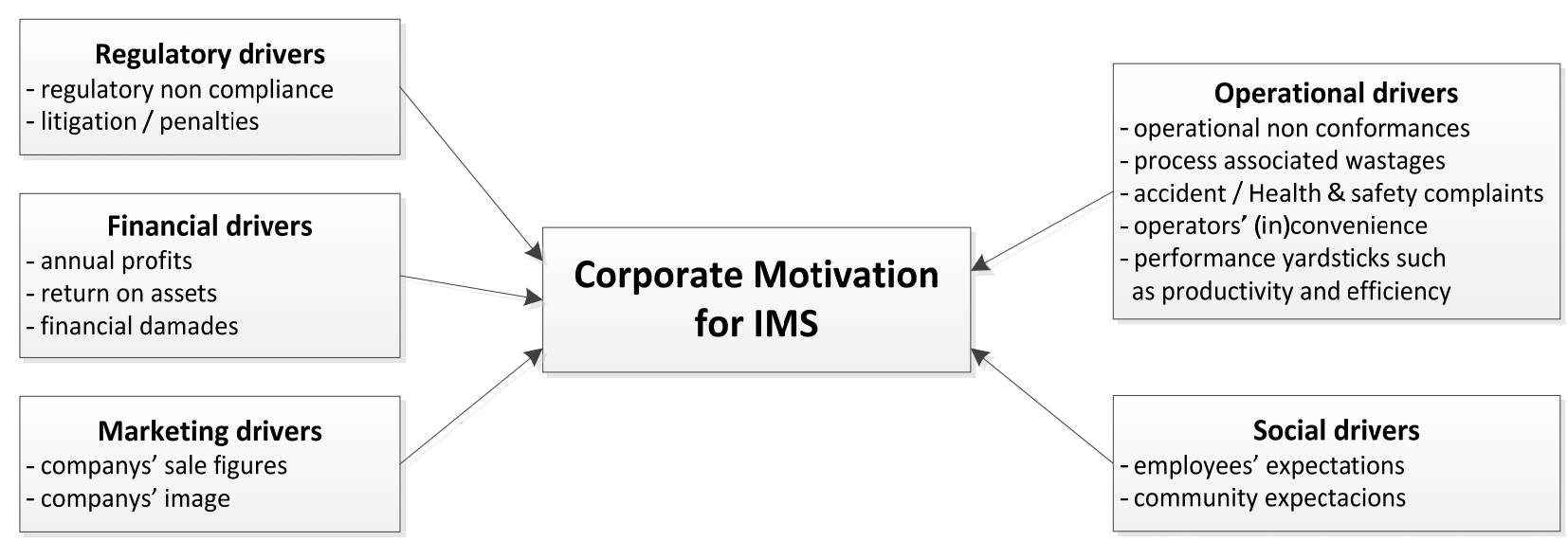

Figure 2. Model of corporate motivation for IMS implementation

(source: [1])

Guidelines and standards have also been developed within individual countries to meet local needs, for example, guides developed by British Standardization Institute (BSI):

- BS 8900-1:2013 "Managing sustainable development of organizations Part 1: Guide", which provides guidance on managing SD and a framework that assists organizations to enhance performance and effectiveness,

- BS 8900-2:2013 "Managing sustainable development of organizations. Framework for assessment against BS 8900-1. Specification”, which acts as an evaluative framework to support organizational selfassessment or third-party assessment and result in formative outcomes.

Several papers have focused on an integrated management systems approach to SD. Enterprises which implemented several various management standards often integrate them into one coherent management system, and factors driving integration process include: regulatory drivers, financial drivers, social drivers, etc. (see Fig. 2).

Integration of management systems such as for quality, environment, occupational health and safety, risk management, and corporate social responsibilities is a viable organizational approach to cost reduction, efficient utilization of resources, greater motivation of employees, and better compliance with social obligations and stakeholders' requirements [40, 37, 61, 38 and 2]. In the context of SD, based on the Brundtland definition of $\mathrm{SD}$, companies are asked to manage resources in such a way that we do not impair the possibility of future generations to satisfy their needs. This means that the future generations as customers, society and employees also are stakeholders. Developing inte- grated management system enables including requirements and expectations of various stakeholders and enables various stakeholders to facilitate IMS development [35].

The second group includes the approaches in which basis for the implementation of SD are business excellence models, such as the European Framework for Quality Management (EFQM) and the Baldrige Criteria for Performance Excellence [7, 3, 11]. The possible linkages between corporate SD and the EFQM are further highlighted by Isaksson and Garvare [29]. As these authors have shown, the EFQM could provide a starting point for the integration of sustainability into business processes. While it is a potentially useful starting point, the EFQM does not provide a comprehensive model for organizational sustainability [4].

The third group includes the approaches benefiting from various management methodologies, standards, and good practices, e.g. codes. The interesting example of a solution within the group is a model developed by Asif \& Searcy [4], so-called Sustainable Development Management System (SDMS) model. According to Asif and Searcy [4], "The systematic implementation and assessment of corporate sustainable development is difficult in the absence of a structured approach. The existing management systems and frameworks do not provide a balanced approach to the management of the triple bottom line of sustainable development." Reaching out to the need of business environment, they developed SDMS, described its elements (Table 1), developed the model (Fig. 3) and defined standard requirements for management systems in Plan-DoCheck-Act (PDCA) cycle context. 
Table 1. The core descriptive elements in a SDMS

(source: [4])

\begin{tabular}{|c|c|}
\hline $\begin{array}{l}\mathrm{SD} \\
\text { core values }\end{array}$ & Characteristics \\
\hline Stakeholder-oriented management & $\begin{array}{l}\text { The concept of sustainability is centered on the need to address } \\
\text { stakeholder requirements in a systematic and integrated manner }\end{array}$ \\
\hline Triple bottom line & $\begin{array}{l}\text { Organizations need to understand the social, environmental, } \\
\text { and economic implications of their business. } \\
\text { The measures should be taken to ensure that business processes } \\
\text { of an organization do not adversely affect these three bottom lines }\end{array}$ \\
\hline Systematic approach & $\begin{array}{l}\text { Organizations need a systematic approach to the management of SD. } \\
\text { A systematic approach is reflected in the: } \\
\text { - management by facts, } \\
\text { - a focus on results and creating value, and } \\
\text { - a systems perspective on managing SD }\end{array}$ \\
\hline Strategic management & $\begin{array}{l}\text { SD needs to be addressed strategically through the visible commitment } \\
\text { of top management. The tactical processes and operational activities } \\
\text { need to be aligned with the organization's strategic priorities }\end{array}$ \\
\hline Innovation and learning & $\begin{array}{l}\text { Organizations need to ensure never-ending improvement, innovation, } \\
\text { and learning along all dimensions of stakeholder requirements }\end{array}$ \\
\hline
\end{tabular}

SD: Sustainable development

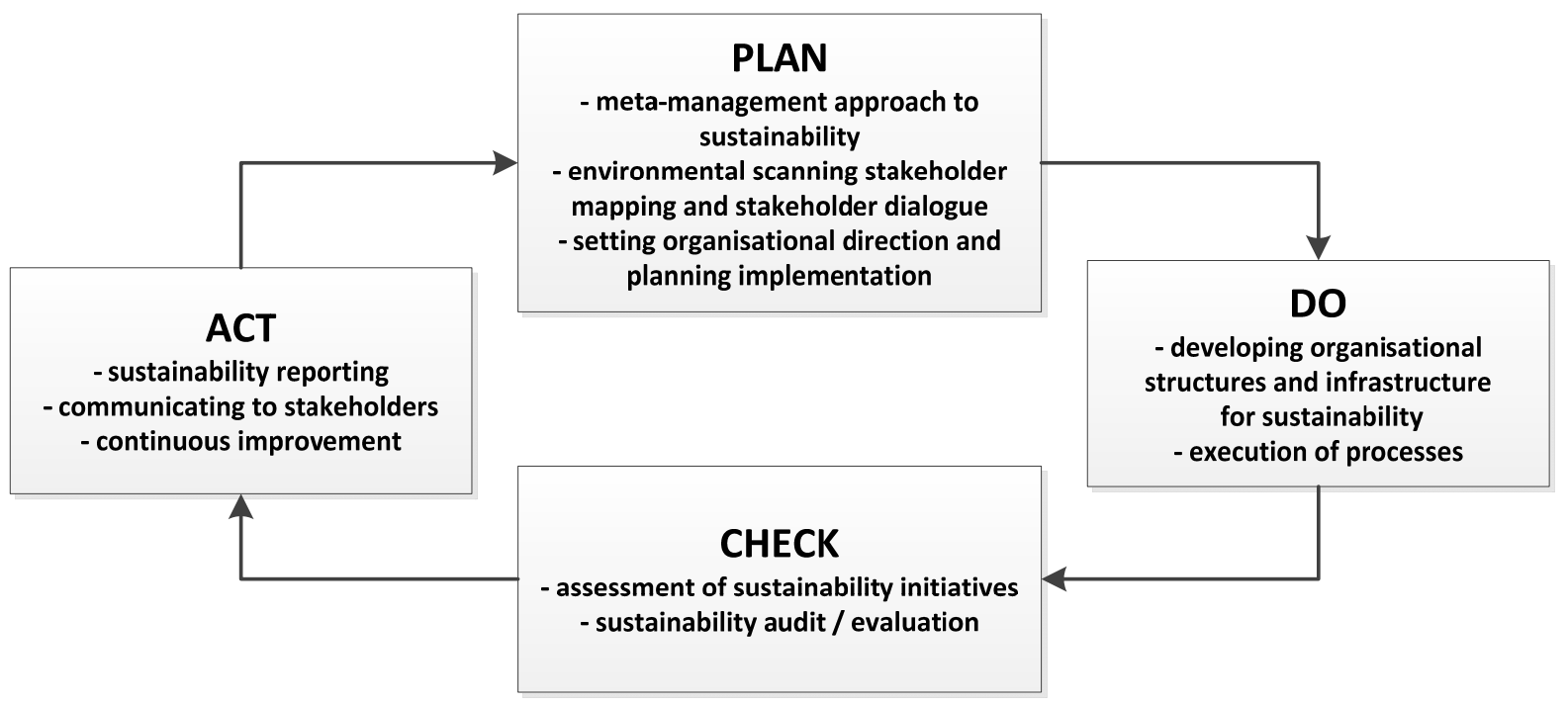

Figure 3. Management of organizational sustainability based on the PDCA cycle (source: [4])

According to authors, the PDCA-based structure of the SDMS makes it possible to integrate it with other standards, including ISO 9001, ISO 14001, OHSAS 18001 and other specification standards.

Summarizing, the approaches presented above interchangeably show that implementing SD into business processes requires strategic approach, including commitment of top managers, incorporating SD into vision and mission of a company, as well as setting principles and practices at all the levels of organization. Boechat et al. [6] identified three dimensions, which are essential in translating sustainability issues into strategic priorities for firms and managers:

1) Identify strategic sustainability issues - a material concept of sustainability, must be understood in order to define risks and opportunities and their relation with the firm's business strategy, transforming them into a source of competitive advantages. 


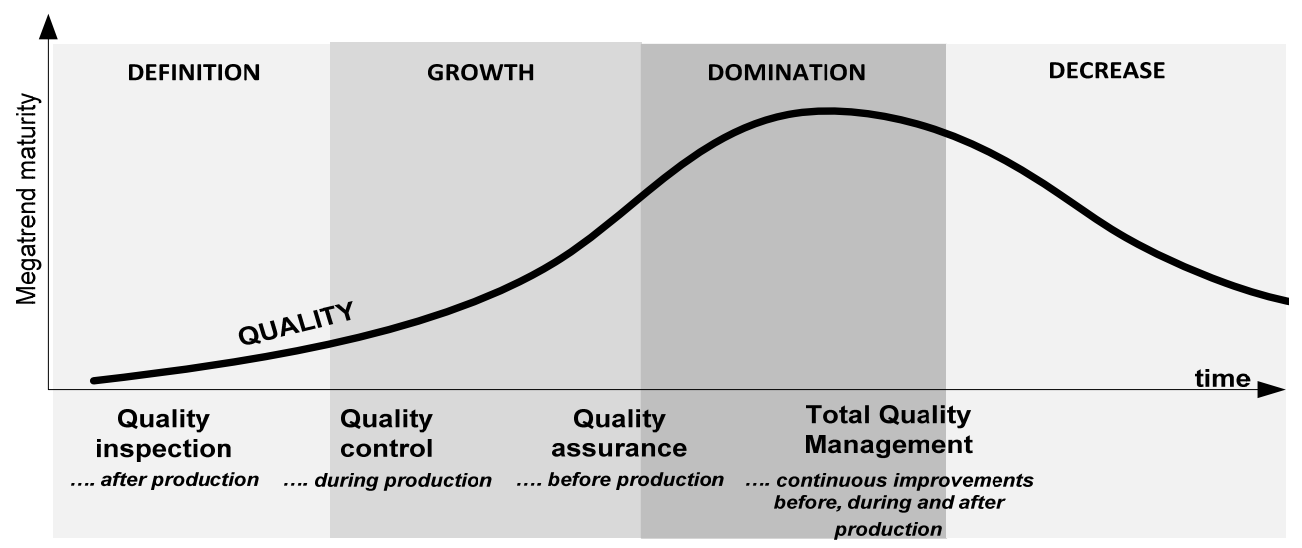

Figure 4. Life cycle of a mega trend "Quality"

2) Cascade strategic priorities in supply chain - engage supply chain partners in order to leverage financial, social and environmental performance.

3) Involve corporate departments and corporate functions - promoting sustainability in a company has to be a process that is shared amongst its different business units. Only once each unit identifies its most relevant activities will their consolidated impact benefit a company's triple bottom line performance.

The success of a SD process depends, above all, on the quality of the process by which it is realized. SD is not a property and is not a fixed state of constancy but a process of directional change by which a system improves through time in a sustainable way. SD is a learning process. This continuous improvement process should slowly but surely be integrated into existing company structure and procedures.

Taking into account the fact that the approach which acts the longest at the operational level and confirms its effectiveness in many organizations worldwide is QM, the question arises whether SD issues could be effectively operationalized by including them into QM system functioning in an enterprise.

\section{Quality management - from reactive to proactive approach}

Similar to sustainability, quality is a broad, multiinterpretable, relative and dynamic concept. Many ways of defining and interpreting quality term in utilitarian sense refers to the level of noticing and range of problems it contains in a company. According to L. Wasilewski [74] "if for any reasons we have to define the term quality, we have to adjust it to the level of sys- tem development in a company. (...). As their quality system is developing, companies change main dimensions of quality definition and measures they use". Such evolutionary character of the tem quality can be found in scientific works of [16, 28 and 44].

D.A. Lubin and D.C. Esty [49], defined actions undertaken in companies to achieve quality as one of megatrends in management. The term "mega-trends" was coined and popularized by John Naisbitt in 1982. He defined mega-trends as broad processes embracing the world, having socio-economic or structural character and influencing a unit and shaping its future [54]. Broader definition was introduced by [70], as they defined mega-trends as "global, solid and macroeconomic development forces, which influence business, economy, society, culture and private life and by that defining our future world and its growing pace of changes".

Development of "mega-trend" can be presented in the form of a product life-cycle model, with four specific stages [62]:

- stage 1 - Definition, which is convergence of trends connected, leading to creation of mega-trend

- stage 2 - Growth, which is fast manifestation of mega-trend and spreading its influence on business, industry and lifestyle.

- stage 3 - Domination, the stage refers to the results of mega-trend and its influence on all the areas of social and economic life.

- stage 4 - Decrease, which is a period in which mega-trend is so common that it is treated as a normal thing.

In the following paper, the following approaches to "quality" mega-trends analysis were applied (see Fig. 4). 
The first stage of QM development is quality inspection. It originates in XIX century, as then because of industrialization, mass production, specialization, and work division became the leading paradigms [43]. At this stage, quality was mostly connected with products and the focus was on inspection of some critical characteristics of final products referred to predefined requirements - specifications. The goal of the inspection was identification of final products not meeting requirements specified, and afterwards, if possible implementation of corrections, and if not selling products at lower prices. The main task of managers in an enterprise was keeping efficiency at the high level, while quality inspection was performed by inspectors trained and representing pre-formed quality departments, so production staff was not involved. Along with economic development and production scale growth, inspection costs have been growing and did not give the results expected by the owners. It was noted that by inspection it is impossible to provide an appropriate level of quality [53].

The scope of activities charged with quality started to extend the processes of production. This stage of development and the perception of quality in the company in the literature is called quality control. By contributing to the quality employees were included in the production, drew attention to the skills of workers supervised by them formally established requirements and standards for their implementation. Feedback was created between the result of control and production line. Based on the results of checks, production process was modified so as to obtain products that met the specifications. As in the run-up, the producers did not have much difficulty in disposing of the products, and therefore did not have to take into account customer feedback. During this period primarily refined receiver subsystems and supply the current and final product inspection, not paying attention to the information coming from the market. Producer's market caused that customers were forced to accept conditions defined by producers. Whereas customers were interested mostly in access to products, their quality was of a secondary importance. Dissatisfaction of customers, if appeared, was mitigated by replacing or repairing defective products.

Summing up. In the first two stages of QM development, actions were focused on detecting discrepancies and taking up reactive corrective actions. The thinking was departmentally based and did not usually directly involve suppliers or customers.

The central idea in the quality assurance (next stage) is that quality of output can only be achieved by organizations that are in control of their processes and functions, and that try to continually improve themselves. This stage, directs organizational efforts towards planning and preventing problems occurring at source. Emphasis is shifted from mere detection to training, product design, process design, process control and motivation of people. Factors creating product quality were taken into account, even if they were not directly connected with manufacturing area - but a part of pre-production and post-production processes. In pre-production, the stress was put on materials and sub-assemblies deliveries, suppliers qualification procedures, requiring implementation of pro-quality solutions by suppliers, so that they covered the entire manufacturing process. In post-production area, pro-quality actions included improvement in post-sale services, creating premises for embracing the entire product lifecycle. The next step in striving for providing products of quality was adjusting organization to quality requirements defined by customers and users of products and services. The postulates emerged for developing solutions which would embrace in systematic way requirements necessary to achieve quality expected by customers. The first system-based solutions, including the entire nets of co-operational requirements, were developed in the USA (f.ex. MIL-Q-9858). In Europe, the earliest interest in the field was in the Great Britain. In 1972, BSI published BS4891standard - "A guide for providing quality". Soon, other European countries followed the Great Britain. Internationalization of economic exchange and variety of requirements included in national standards led to necessity of coordinating normalization actions and taking up development of systematic international solutions. In 1987, the ISO published the first edition of its 9000 standards.

From the very beginning, the standards were classified as so called third-generation standards, which means they are completely different from industrial standards, focusing f.ex. on product's characteristics. Thus, their basic assumption was the idea of standardizing general methodologies of managerial practice, bringing benefits to both, suppliers and customers [43]. 


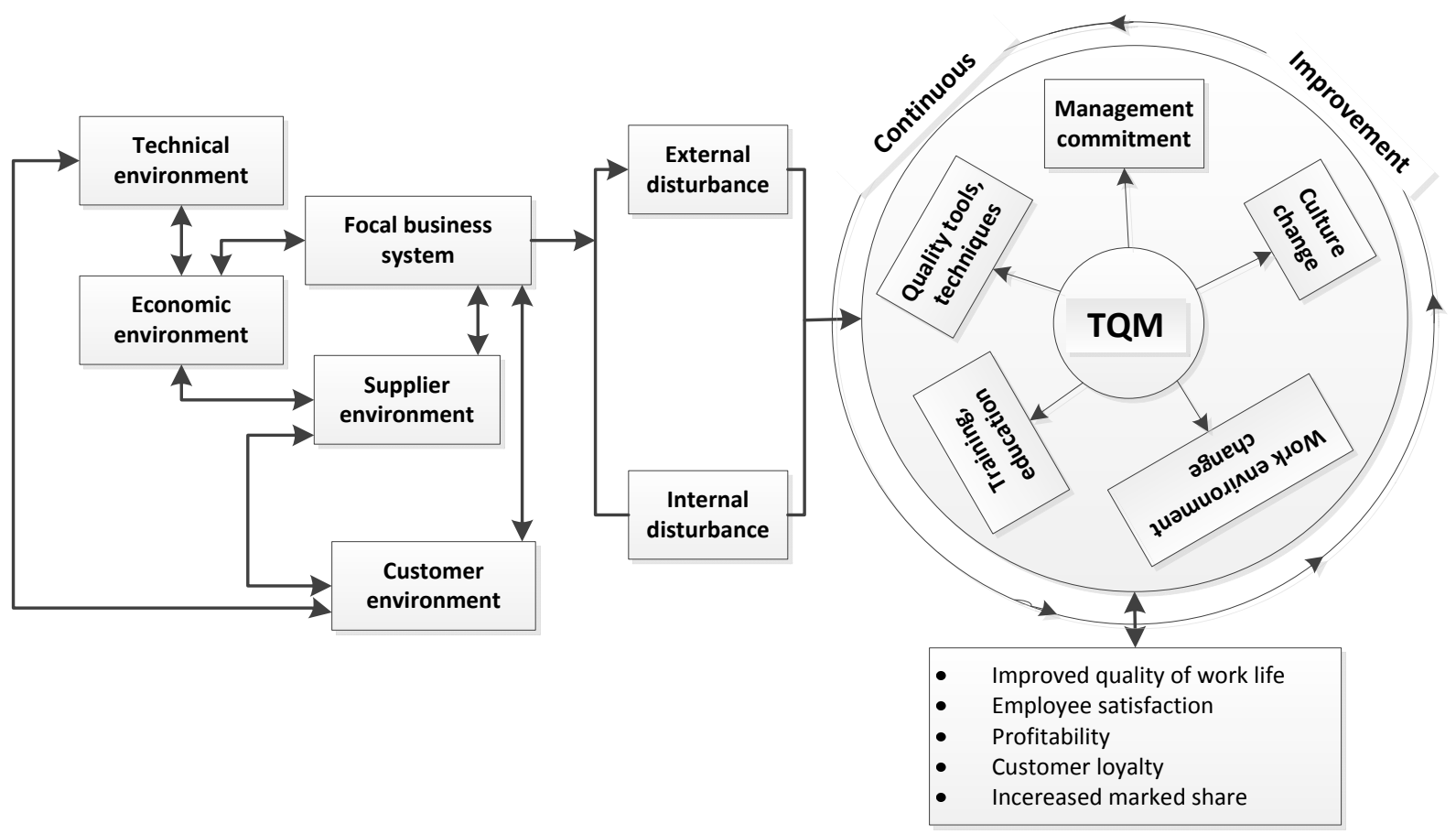

Figure 5. Effect of Interactive Environment on Business System (source: [45])

The fourth stage, can be described as total quality management (TQM), where quality has become a strategic issue and its scope extended to the quality of the organization and the quality of the relationship with the environment of an organization (customers, suppliers, competitors, the public in general) and their integration with horizontal business processes [8]. This paradigm states that the responsibility for quality lies not with one department or one person (the representative of the management), but the whole organization needs to take responsibility for quality and take it as a common value [55]. The objective of TQM as suggested by Lakhe \&
Mohanty [45] is to identify and recognize the external environment (i.e. supplier environment, customer environment, economic, and technological environment) and create conditions within the focal system to maintain internal balance and eventually gain external equilibrium (see Fig. 5).

TQM is multidimensional approach analyzed in the following aspects, that is: strategic, marketing, technological, economic, organizational, social, and systembased [72]. Various interpretation of TQM approaches is a results of taking various definition criteria (Table 2).

Table 2. Various TQM interpretations

(source: [72])

\begin{tabular}{|l|l|}
\hline \multicolumn{1}{|c|}{ TQM definition criteria } & \multicolumn{1}{c|}{ Characteristics } \\
\hline In activity-based approach & $\begin{array}{l}\text { TQM is a process, its strategic market goal is increase of competitiveness } \\
\text { and company's value }\end{array}$ \\
\hline In operational approach & $\begin{array}{l}\text { Goal of TQM is achieving desired size and structure of results of actions } \\
\text { undertaken by a company }\end{array}$ \\
\hline In objective approach & $\begin{array}{l}\text { TQM is an approach of corporate management that strives for meeting re- } \\
\text { quirements and expectations of customers }\end{array}$ \\
\hline In subjective approach & $\begin{array}{l}\text { Refers to all the employees of an enterprise, hence it is dedicated to both, } \\
\text { managers and their subordinates }\end{array}$ \\
\hline In functional approach & $\begin{array}{l}\text { Refers to all the areas of economic activity, together with interdependencies } \\
\text { involved }\end{array}$ \\
\hline
\end{tabular}

TQM: Total quality management 


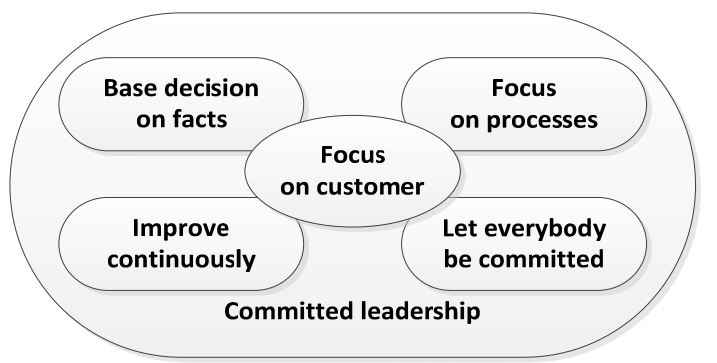

Figure 6. The core values of TQM (source: [28])

TQM may be defined as a continuous quest for excellence by creating the right skills and attitudes in people to prevent defects possible and satisfy customers/users totally at all times [45]. Hellsten \& Klefsjö [28] defined TQM, as a continuously evolving management system consisting of values, methodologies and tools, the aim of which is to increase external and internal customer satisfaction with less resource consumption.and introduced core values, which should be used to characterize this approach to quality in an enterprise (Figure 6).

Praxiom Research Group Limited (2003, cited by [59]) defined TQM as a management approach that tries to achieve and sustain long-term organizational success by encouraging employee feedback and participation, satisfying customer needs and expectations, respecting societal values and beliefs, and obeying governmental statutes and regulations. Independently from the level of precision in TQM definitions presented in the literature, there are some common elements of TQM stressed, namely: top management commitment, everybody's commitment, continuous improvement, focus on customer, focus on process, and using facts-based approach for decision making.

Research on the literature related to the subject shows that the successful implementation of TQM can lead to a wide range of benefits for organizations. These benefits include higher profits, growth and efficiency, increased market shares, reduced operational cost, productivity, and innovation [45, 33, 14, 63 and 47].

Nevertheless, because of the lack of generally accepted universal TQM model, many companies "turn back" from the approach searching for improvement guidelines in quality awards and models [64, 42]. Confirmation of the pre-mentioned "turning back" from that approach to management is TQM application tendency observation. Whereas in 1993, TQM was applied in $72 \%$ of analyzed companies, in 2000 the number fell down to $41 \%$ only, and in 2008 the number reached $34 \%$ [60]. It is on hand the result of a "fashion" (the term "quality" is a bit old and out-of-date compared to fresh and nowadays catchy "excellence"), and on the other the consequence of the situation that the criteria of the original quality awards (e.g. EFQM, MBQA) successively over the years widened their perspectives in harmony with discussions related to environmental issues and social responsibility.

Edited in 2000, the next version of ISO 9001:2000 standard adopts TQM philosophy with stronger focus on customer satisfaction and an effective processoriented approach, emphasizing on continual performance improvement (in 2008 there was the next amendment; however, no important differences compared to previous editions were introduced). In the standard, the stress is put on the fact, that organizations depend on their customers and therefore, should understand them current and the future need; they will meet these requirements, while taking care to exceed customer expectations. "Quality" is delivering an output meeting or exceeding customer's expectations. The client is the frame of reference for answering the question "What is quality?", including the nature of quality as well as the needed or appropriate level. This new revised standard is a step forward towards TQM, customer satisfaction and does not just achieve product quality assurance.

Summing up. The third and the fourth stage of quality mega-trend development indicate that there is a substantial change in approach to quality. The models presented above are oriented neither to a given product, service nor quality control methodology, but to broadly understand corporate management and processes influencing final products.

What then is to be the next stage in the evolution of QM after TQM. As we have seen, TQM has been characterized by strong focus on the following issues:

- espoused organizational values supported by methodologies and tools,

- customer focus and satisfaction, 


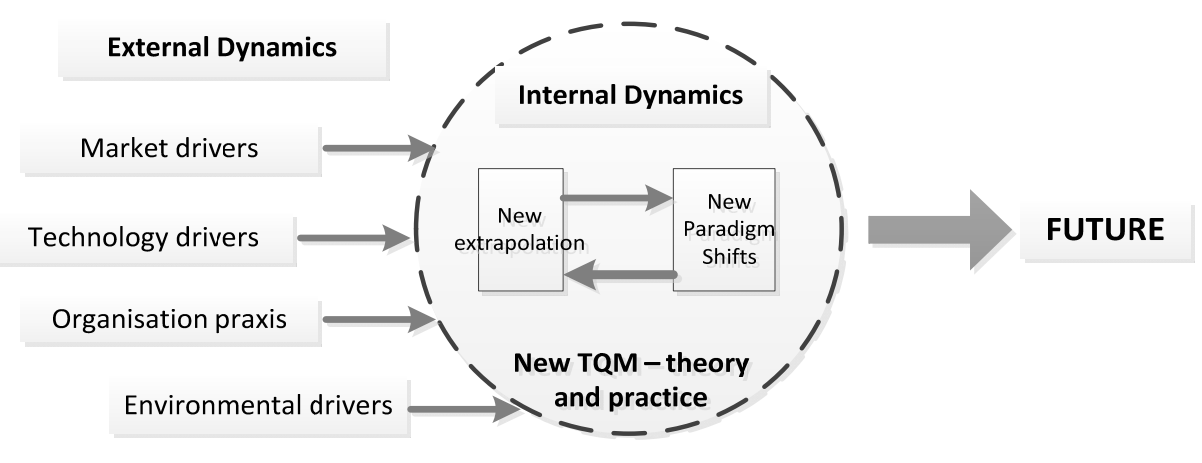

Figure 7. Model of internal and external TQM drivers (source: [50])

- efficient use of resources,

- continuous monitoring and assessment of improvement potentials.

What will be its characteristics and focus in the future?

\section{$4 \quad$ Sustainable quality managemant}

Searching for answers to questions presented in the previous chapter, requires referring to the model presented in the figure. Nowadays, we are at the fourth stage of the cycle. It means that "quality" megatrend is in its decreasing stage, hence it is the "normal" approach from the company's point of view. However, assuming that QM impact on organization will continue, question on the types of QM based improvement initiatives that will develop in the future to meet the anticipated organizational and market changes seems to be justified. And even though because of increasing complexity, discontinuity and pace of changes, future forecasting is almost impossible, we still can and should try to forecast future. Identification of direction that QM will evolve in, is valuable in cognitive and utilitarian sense. It is to enable the understanding of external challenges, which are unavoidable, and make developing scenarios easier by providing guidelines useful in decision on shaping QM system in companies making process.

Future QM in a company will be shaped by two kinds of factors (Figure 7): external, which refers to changes in business environment, and internal, which refers to issues within QM movement.

External factors, which currently most influence company's functioning and the way its strategy is shaped, are challenges brought by SD. SD is the next megatrend in management [49]. Through the next years, this trend will shape trends and force sustained changes in methodologies of actions taken and building competitive advantage of companies. Thus, organizations should identify the trends, assess their influence on its activity and opportunities it creates, and include and integrate them to binding business strategy.

Analysis of both approaches presented, SD and quality [34], leads to the conclusion that they have much in common:

- Both have gone through a historical and conceptual progression from passive reactivity to proactive, strategic integration. Over the years, quality issues have evolved from being focused on product performance to comprehensively addressing business excellence. Similarly, SD for many years was associated with environmental aspects and degradation of natural environment caused by civilization development only, while now it is a broad concept referring to such terms as "quality of life" and "corporate social responsibility".

- Both impact satisfaction, well-being and safety of customers, employees and other stakeholders. In QM, customer focus has evolved into the broader concepts of interested parties, human stakeholders, environmental stakeholders and societal sustainability [24].

- Both are based on a core set of values, such as "create zero waste," "make external costs visible," and "drive out fear" between management and employees [71]. Like quality, SD also has a strong focus on people - not just in terms of customer satisfaction, but related to the quality of working life and employee satisfaction.

- Both impact, and are impacted by, every function in the organization. Just as a customer's perception of quality is affected by everything including product design and development, manufacturing, logistics, interactions with marketing, sales, customer 


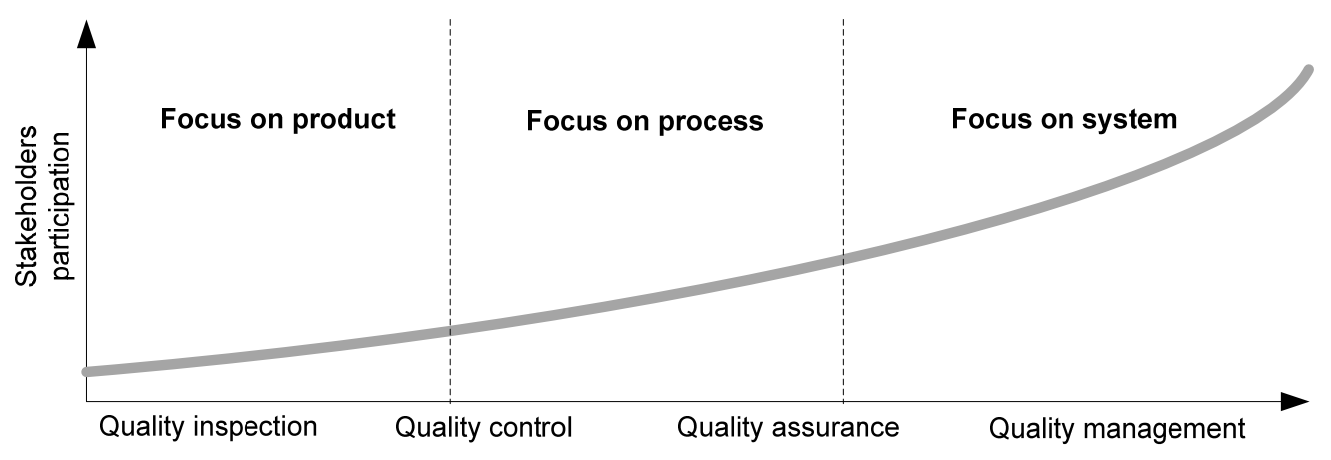

Figure 8. Stakeholders' participation in quality approaches

service and more, so too is sustainability impacted by every function within the organization. Like sustainability on the societal level, the SD of a company requires the involvement of a variety of company-internal actors, since many challenges of sustainability management demand the contribution of several corporate functions [66]. The involvement of all functional units is considered to be necessary to create comprehensive sustainability solutions and to impede sustainability problems from being partially or superficially "solved" or from being shifted back and forth between functional units [67].

- Both are based on continuous improvement towards a performance ideal: a company will never reach perfection in either quality or sustainability, and it is also never "done," but rather always striving to improve towards the goal of perfection.

- Both, if done well, help drive significant financial and strategic benefits to the organization in the form of scrap and rework reduction, cost reductions, increased profitability, improved reputation and customer loyalty.

- In both, senior management holds complete responsibility. The majority of quality problems are the fault of poor management rather than poor workmanship. Likewise, corporate sustainability success is directly related to CEO commitment. Value creation is driven through executive buy-in and execution throughout the organization [46].

Taking into account challenges brought by SD to managers (see chapter 2) and common elements of both mega-trends introduced above, it is clear that the important element of each stage of evolution of QM is "transactivity" term, which lies at the basis of link between organization and its broader social context. The term is a key relation between QM idea, and the idea more and more important, that is corporate social responsibility; moreover, it is an attempt to draw the attention of managers to the necessity of reacting to needs and requirements of diverse stakeholder groups. Numerous management principles and techniques are focused on needs and requirements of various groups. The groups mentioned are, and for many years were, customers, now accompanied by employees and suppliers. However, growing complexity of environment company is functioning in, as well as growing access to information, indicate the need of considering more and more diverse group of stakeholders within an organization and outside of it, with their needs and requirements (see Fig. 8).

Expectations of stakeholders are not only focused directly on transactions between parties involved, but also on participation in a debate on social issues (e.g. unemployment, poverty, etc) and proactive consideration of results and effects of activity on society.

Hence, contemporary company according to [58, p. 17] is an organization engaged in mobilizing resources for productive uses in order to create wealth and other benefits (and not intentionally destroy wealth, increase risk, or cause harm) for its multiple constituents, or stakeholders. In that aspect, organizational wealth is defined as "a mean of summarized ability of an organization to create benefits for each and every stakeholder in a long time period" [58, p. 45].

Such increasing care for society is imminent part of QM approach. The new approach to thinking about quality requires taking a look at definition of TQM presented in ISO 8402:1994 standard and at "customer" definition by Crosby. In ISO 8402 [32] standard published in 1994, TQM is defined as "methodology of managing an organization based on cooperation of all its members. 
It stresses quality issues and by satisfying customers leads to achieving perspective success of an organization, its employees and society." From TQM definition perspective, it is justified to incorporate social responsibility issues into business strategy. Thus, the direction in which QM strives for, was defined 30 years ago and is still accurate. While its realization by organization depends on the definition of "customer" applied.

In recent years, indications are that the scope of QM has begun to change from "customer satisfaction" into something broader. Specific gravity has moved to providing work conditions, including work culture and quality of relations with environment and social responsibility [48]. The ISO 9001:2005 standard promotes a narrow definition of the customer as an "organization or person that receives a product." Examples include the consumer, client, end-user, retailer, beneficiary and purchaser. According to the standard, a customer can also be internal or external to the organization. Though the standard gives some further explanation for the definition its range is quite narrow. While according to Ishikawa [31] the customer is simply the process that follows ("the next process is your customer"). A broader definition was suggested by J. Juran [39], who defined customer as "anyone who is affected by the product or by the process used to produce the product" where the customer can also be a local community, the environment, and even future generations. This broad definition of "client" is close to the notion of "stakeholder". The term is often used in the sense of those who have a "stake" in the organization. The most famous, but the most general definition of stakeholders was presented by E. Freeman in 1984. According to [22]: "a stakeholder is any person or group that can affect or is affected by the achievement of the organization's objectives". This definition has been the subject of discussion and deliberations in literature [15, 17, 23, 51]. In the model of excellence Malcolm Baldrige National Quality Award (MBNQA) 2011-12, the term "stakeholders" refers to all groups that are or may be affected by the activities of the organization and its success. The EFQM Excellence Model 2010 [19], defines stakeholders as: "a person, group, or organization that has direct or indirect ownership or interest in the organization because it can affect or be affected by the organization or its influence." This approach is close to the definition of Freeman.

Hence, answer to the question whether SD is an issue for QM, is based on the discussion by [5]. They believe that if "quality management is seen as managing quality improvements of goods and services aiming to maximize customer satisfaction subject to meeting the needs and expectations of non-customer stakeholders, then we could choose the boundaries of quality management simply by selecting an appropriate customer definition. If we use a wide definition which could include many different groups of stakeholders, Quality Management should become something similar to Business Management. On the other hand, if we use a narrow definition of customers, Quality Management becomes something much more limited in scope" [5]. Foley $[2005$, p. 10] argues that if the organization can continue to meet the needs and expectations of the stakeholders, the aim of organizational sustainability will be accomplished. Foley \& Zahner [21] have used the definition of the stakeholder to construct an organization sustainability model, which in its consideration of quality as one of the wants and expectations of stakeholders, and as a strategy for guiding the organization to sustainable success, generates a form of QM.

In the next edition of ISO9001, planned for 2015, the stress is put on stakeholders and necessity for sustainable approach to their requirements and expectations via assessment of opportunities and risk emerging from their influence on organizational success. The element binding new and old is the term "stakeholder" and responsibility of an organization for its influence on society [37].

Quality movement moves towards corporate order and elimination of negative influence on environment. It focuses on solving multi-dimensional problems, benefiting from broad definition of "complex quality," referring to all the aspects of social systems, both in public and private sectors. QM works as a main catalyzer of development of corporate social responsibility in an organization. This concept is seen as an approach of running a business in society and environment friendly way, while meeting the most important goal of economic activity, which is increasing wealth of business stockholders. Therefore, it indicates that it is possible to compromise moral principles and rational economic rules, balancing striving for profits and searching for rationale and doing the right thing in terms of respecting interests of wider groups of stakeholders. Hence, QM models (e.g. ISO 9001) can play an important role in facilitating broad social and environmental dimension introduction to corporate strategy, and supporting organization in realization of SD approach. 
Thus, it is justified to define the next stage of approach to quality as sustainable QM, which can be management framework for improving quality of corporate development towards SD. However, in the approach, instead of introducing additional set of procedures and processes defining relations between an organization and its stakeholders, theory and practice requires generally various processes, which hitherto were not a part of a normal practice of quality approach. These processes should be capable of dealing with complex problems that are not limited to the subjects traditionally believed to be external. They can embrace any of or all the stakeholders.

\section{Conclusions}

Over a half-century ago, quality pioneers Edwards Deming and Joseph Juran encouraged organizations to ask better questions about corporate challenges and enabled companies to redesign systems for improvement. They started with a systems approach and then grounded quality in practical analytical tools to foster product, service, and organizational improvements.

Today's SD frameworks encourage businesses to ask better questions about impacts on stakeholders, society, and the environment, and they seek to develop the tools and measures needed to demonstrate improvements. The sustainability of the organization relies on its ability to monitor the external environment for opportunities, changes, trends and risks, and also its ability to learn, change and innovate in response to the results of monitoring. To achieve sustainability, the organization should focus on its results as well as on its processes.

While there has been criticism for many years, still QM philosophy continues to be a central focus for business and mechanism for contributing to better performance. Over the years QM has evolved to become more and more encompassing through the integration of various processes and activities. Sustainability does, however, mean that QM should not be left as an "act of faith" but needs to be managed through taking a strategic perspective, emphasis on measurement and taking action and a continual focus not only on the end customer to meet requirements but also on all those which by their products or processes interact. To rise to the challenges of SD and support companies in reali- zation of this management approach, $\mathrm{QM}$ has to be:

- integrative: integrating linked human-environment systems - in order to integrate systems, departments to achieve whole system sustainability,

- inclusive: participatory-based - in order to accommodate multiple perspectives and understand undecidability, and to generate adaptive and innovative capacity,

- adaptive: supporting adaptive modeling of transitions to provide decision-support to adaptive management efforts - in order to be able to adapt to real-world changes as they occur.

I think that there are many ways in which experience in quality managemnt and knowledge in the area can support enterprises in realization of the challenges emerging from SD realization.

However, support seems not to be enough. It is necessary to define activities in the area of QM which need to be carried out and not to exist for managers only as "somtehing obvious and normal" (fourth stage of a lifecycle), but also as the source of inspiration in creating value for stakeholders and support in solving potential and existing problems.

\section{$6 \quad$ References}

[1] Asif M., de Bruijn E.J., Fissche, O.A.M. - Corporate motivation for integrated management system implementation: why do firms engage in integration of management systems: a literature review \& research agenda [in] 16th Annual High Technology Small Firms Conference, HTSF 2008, 21-23 May 2008, Enschede, The Netherlands http://doc.utwente.n1/73735/1/Asif.pdf (accessed on 29.09.2014)

[2] Asif M., de Bruin E.J. Fisscher O.A.M. - Process embedded design of integrated management systems [in] International Journal of Quality \& Reliability Management, Vol. 25, No. 3, 2008, pp. 261282.

[3] Asif M., Searcy C., Garvare, R. Ahmad N. - Including sustainability in business excellence model [in] Total Quality Management \& Business Excellence, Vol. 22, No. 7, 2011, pp. 773-786.

[4] Asif M., Searcy C. - Towards a standardised management system for corporate sustainable development [in] The TQM Journal, Vol. 26, No. 5, 2014, pp. 411-430. 
[5] Bergquist B., Garvare R. Klefsjö B. - Quality Management for tomorrow [in] To appear in Quality (ed. K. Matters Foley, D. Hensler, J. Jonker). SAI Global, Sydney, Australia 2006

[6] Boechat C., Maria Raquel Grassi F. Marques, Spitzeck H., Tello R., Seixas B. - Total Quality Management (TQM) for Sustainability, CDSC Centro de Desenuoluimento da Sustentabilidatede na Construcao, 2013.

[7] Bolboli S.A., Reiche M. - A model for sustainable business excellence: implementation and the roadmap [in] The TQM Journal, Vol. 25, No. 4, 2013, pp. 331-346

[8] Borys T., Rogala P. - Systemy zarzqdzania jakościa i środowiskiem. Wydawnictwo Uniwersytetu Ekonomicznego we Wrocławiu, Wrocław 2012

[9] BS 8900:2006 Guidance for managing sustainable development

[10] Business Dictionary, 2014

http://www.businessdictionary.com/definition/susta inability.html

[11] Butlewski M., Misztal A., Jasiulewicz-Kaczmarek M., Janik S. - Ergonomic and work safety evaluation criteria of process excellence in the foundry industry [in] Metalurgija, No. 53/ 4, 2014, pp. 701704

[12] Butlewski M., Misztal A., Ciulu R. - Non-financial factors of job satisfaction in the development of a safety culture based on examples from Poland and Romania [in] Lecture Notes in Computer Science Springer International Publishing, Vol. 8529, 2014, pp. 577-587.

[13] Castka P., Balzarova M.A. - The impact of ISO 9000 and ISO 14000 on standardisation of social responsibility - an inside perspective [in] International Journal of Production Economics, Vol. 113, No. 1, 2008, pp. 74-87

[14] Chin K.S., Pun K.F. - A proposed framework for implementing TQM in Chinese organizations [in] The International Journal of Quality and Reliability Management, Vol. 19, No. 3, 2002, pp. 272294.

[15] Clarkson M. - A risk based model of stakeholder theory [at] Proceedings of the Second Toronto Conference on Stakeholder Theory. Toronto: Centre for Corporate Social Performance \& Ethics, University of Toronto, 1994.

[16] Dale B.G., Zairi M., Van der Wiele A., Williams A.R.T. - Quality is dead in Europe - Long Live Excellence, true or false? [in] Measuring Business Excellence, Vol. 4, No. 3, 2000, pp. 4-10.
[17] Donaldson T., Preston L.E. - The Stakeholder Theory of the Corporation: Concepts, Evidence, and Implications [in] Academy of Management Review, Vol. 20, No. 1, 1995, pp. 65-91

[18] Edgeman R.L., Hensler D.A. - The AQ Chronicle: Earth@Omega or Sustainability@Alpha? [in] The TQM Magazine, Vol. 13, No. 2, 2001, pp. 83-90.

[19] EFQM - User Guide Understanding an organisation's stakeholders. EFQM Publications, 2010, pp. 2.

[20] Flanagan K., Green L., Malik K., Miles I. - The Future of Manufacturing in Europe 2015-2020: The Challenge for Sustainability, 2003, http://foresight.jrc.ec.europa.eu/documents/eur207 05en.pdf (accessed on 30.09.2014).

[21] Foley K., Zahner T. - Creating and Managing the Sustainable Organisation: The Stakeholder Way, Sydney: SAI Global 2009.

[22] Freeman R.E. - Strategic management: A stakeholder approach. Boston, MA: Pitman, 1984.

[23] Freeman, R.E. - Toward a New Vision for Management Research: A Commentary on Organizational Researcher Values, Ethical Responsibility, and the Committed-to-Participant Research Perspective [in] Journal of Management Inquiry, Vol. 11, No. 2, 2002, pp. 186-189.

[24] Garvare R., Isaksson R. - Sustainable Development: Extending the Scope of Business Excellence Models [in] Measuring Business Excellence, Vol. 5, No. 3, 2001, pp. 11-15.

[25] Grudzewski W.M., Hejduk I.K. - Przedsiębiorstwo przyszłości. Zmiany paradygmatów zarzqdzania [in] Master of Business Administration 1, 2011 (116), pp. 95-111.

[26] Gunasekaran A., Spalanzani A. - Sustainability of manufacturing and services: Investigations for research and applications [in] International Journal of Production Economics, Vol. 140, No. 1, 2012, pp. 35-47.

[27] Hall C.M. - Sustainable mega-events: beyond the myth of balanced approaches to mega-event sustainability [in] Event Management, Vol. 16, No. 2, 2012, pp. 119-131.

[28] Hellsten U., Klefsjö B. - TQM seen as a management system consisting of values, techniques and tools [in] The TQM Magazine, Vol. 12, No. 4, 2000, pp. 238-244.

[29] Isaksson R., Garvare R. - Measuring sustainable development using process models [in] Managerial Auditing Journal, Vol. 18, No. 3, 2003, pp. 649656. 
[30] Isaksson R. - Total Quality Management for Sustainable Development - process based system models [in] Business Process Management Journal, Vol. 12, No. 5, 2006, pp. 632-645.

[31] Ishikawa K. - What is total quality control? The Japanese way, Englewood Cliffs, NJ: Prentice Hall, 1985, pp.107.

[32] ISO 8402:1994, Quality management and quality assurance - Vocabulary.

[33] Issac G., Rajendran C. and Anantharaman R.N. A conceptual framework for total quality management in software organizations [in] Total Quality Management and Business Excellence, Vol. 15, No. 3, 2004, pp. 307-344.

[34] Jasiulewicz-Kaczmarek M. - Q4S - Quality for Sustainability [at] $8^{\text {th }}$ Research/Expert Conference with International Participations QUALITY 2013, Neum, B\&H, June 06 - 08, 2013, pp. 117-122.

[35] Jasiulewicz-Kaczmarek M., Misztal A. - Projektowanie $i$ integracja systemów zarzqdzania jakościq. Wydawnictwo Politechniki Poznańskiej, Poznań 2014.

[36] Jayal A.D., Badurdee F., Dillon Jr. O.W., Jawahir I.S. - Sustainable manufacturing: Modeling and optimization challenges at the product, process and system levels [in] CIRP Journal of Manufacturing Science and Technology, No. 2, 2010, pp.144-152.

[37] Jørgensen T.H., Remmen A., Mellado M.D. - Integrated management systems-three different levels of integration [in] Journal of Cleaner Production, Vol. 14, No. 8, 2006, pp. 713-722.

[38] Jørgensen T.H. - Towards more sustainable management systems: through life cycle management and integration [in] Journal of Cleaner Production, Vol. 16, No. 10, 2008, pp. 1071-1080.

[39] Juran J. - Quality Control Handbook, 4th ed., McGraw-Hill, New York, NY, 1988, pp. 23.

[40] Karapetrovic, S. - Strategies for the integration of management systems and standards [in] The TQM Magazine, Vol. 14, No. 1, 2002, pp. 61-67.

[41] Kates R.W., Parris T.M., Leiserowitz A.A. - What Is Sustainable Development? Goals, Indicators, Values, and Practice [in] Environment: Science and Policy for Sustainable Development, Vol. 47, No. 3, 2005, pp. 8-21.

[42] Klefsjö B., Bergquist B., Garvare R. - Quality management and business excellence, customers and stakeholders. Do we agree on what we are talking about, and does it matter? [in] The TQM Journal, Vol. 20, No. 2. 2008, pp. 120-129.
[43] Konarzewska- Gubała E. (ed.) - Zarzqdzanie przez jakość, koncepcje, metody, studia przypadków, (Quality management, concepts, methods, case studies). Wydawnictwo Akademii Ekonomicznej, Wrocław 2003.

[44] Lagrosen Y., Lagrosen S. - The effects of quality management - a survey of Swedish quality professionals [in] International Journal of Operations \& Production Management, Vol. 25, No. 9/10, 2005, pp. 940-952.

[45] Lakhe R.R., Mohanty R.P. - Total Quality Management Concepts, Evolution and Acceptability in Developing Economies [in] International Journal of Quality \& Reliability Management, Vol. 11, No. 9, 1994, pp. 9-33.

[46] Lakshman C. - A Theory of Leadership for Quality: Lessons from TQM for Leadership Theory [in] Total Quality Management, Vol. 17, No. 1, 2006, pp. 41-60.

[47] Lee V.H., Ooi K.B., Tan B.I., Chong A.Y.L. A Structural Analysis of the Relationship between TQM Practices and Product Innovation [in] Asian Journal of Technology Innovation, Vol. 18, No. 1, 2010, pp. 73-96.

[48] Lisiecka K. - Kreowanie jakości. Uwarunkowania, strategie, techniki. Wydawnictwo Akademii Ekonomicznej w Katowicach, Katowice 2002.

[49] Lubin D.A., Esty D.C. - The Sustainability Imperative, Harvard Business Rreview, 2010.

[50] McAdam R., Henderson J. - Influencing the future of TQM: internal and external driving factors [in] International Journal of Quality \& Reliability Management, Vol. 21, No. 1, 2004, pp. 51-71.

[51] McVea J.F., Freeman R.E. - A Names-and-Faces Approach to Stakeholder Management. How Focusing on Stakeholders as Individuals Can Bring Ethics and Entrepreneurial Strategy Together [in] Journal of Management Inquiry, Vol. 14, No. 1, 2005, pp. 57-69.

[52] Mock T., Wernke T. - Like Life Itself, Sustainable Development is Fractal, 2011, http://www.triplepundit.com/2011/01/like-lifesustainable-development-fractal/ (accessed on 30.09.2014).

[53] Mrugalska B., Akielaszek-Witczak A., Stetter R. Robust quality control of products with experimental design (ed. D. Popescu), pp. 343-348, International Conference on Production Research Regional Conference Africa, Europe and the Middle East and 3rd International Conference on Quality and Innovation in Engineering and Man- 
agement, Cluj-Napoca, Romania, July 1-5, 2014; Technical University of Cluj-Napoca; ClujNapoca, Romania.

[54] Naisbitt J. - Megatrendy. Dziesięć nowych kierunków zmieniajacych nasze życie. Wydawnictwo Zysk i S-ka, Poznań 1997.

[55] Oakland, J.S. - Total Quality Management. Heinemann Professional, London, 1989.

[56] Pojasek R.B. - ISO 26000 guidance on social responsibility [in] Environmental Quality Management, Vol. 20, No. 3, 2011, pp. 85-93.

[57] Pojasek R.B. - Understanding Sustainability: An Organizational Perspective [in] Environmental Quality Management, Vol. 21, No. 3, 2012, pp. 93100,

[58] Post J.E., Preston L.E., Sachs S. - Redefining the Corporation - Stakeholder Management and Organizational Wealth. Stanford University Press, Stanford, CA. 2002.

[59] Ribière V.M., Khorramshahgol R. - Integrating Total Quality Management and Knowledge Management [in] Journal of Management Systems, Vol. 16, No. 1, 2004, pp. 39-54.

[60] Rigby. D. - Management Tools and Trends 2009 Global Results, Bain \& Company, Boston 2009.

[61] Rocha M., Searcy C., Karapetrovic S. - Integrating sustainable development into existing management systems [in] Total quality management, Vol. 18, No. (1-2), 2007, pp. 83-92.

[62] Rosen M.A., Kishawy H.A. - Sustainable Manufacturing and Design: Concepts, Practices and Needs, Sustainability, No. 4, 2012, pp. 154-174.

[63] Salaheldin I.S. - Critical success factors for TQM implementation and their impact on performance of SMEs [in] International Journal of Productivity and Performance Management, Vol. 58, No. 3, 2009, pp. 215-237.

[64] Sila I., Ebrahimpour M. - An investigation of the total quality management survey-based research published between 1989 and 2000: a literature review [in] International Journal of Quality \& Reliability Management, Vol. 19, No. 7, 2002, pp. 902970.

[65] Schaltegger S., Herzig Ch., Kleiber O., Müller J. Sustainability management in business enterprises. Concepts and Instruments for Sustainable Organisation Development, Published by: The Federal Ministry for the Environment, Nature conservation and Nuclear Safety (BMU) Division for Environment and Economy, 2012 (accessed on 30.09.2014) http://www2.leuphana.de/umanagement/csm/content/ nama/downloads/pdf-ateien/nmu_fs_engl_final.pdf

[66] Schaltegger S., Harms D., Sarah Elena Windolph S.E., Hörisch J. - Involving Corporate Functions: Who Contributes to Sustainable Development? [in] Sustainability, No. 6, 2014, pp. 3064-3085.

[67] Shrivastava P., Hart S. - Creating sustainable corporations [in] Business Strategy and the Environment, No. 4, 1995, pp. 154-165.

[68] Sidorczuk-Pietraszko E. - The concept of sustainable development at organizational level [in] Towards the Theory of Sustainable Development, Polish Academy of Science. Studies on Sustainable Development. 2007, pp. 365.

[69] Sneddon C., Howarth R.B., Norgaard R.B. - Sustainable development in a post-Brundtland world [in] Ecological Economics, Vol. 57, No. 2, 2006, pp. 253-268.

[70] Srinivasan K., Robbins A. - Mega Trends That Will Shape the Future of the World. Frost \& Sullivan, May 2011,

http://corporateventuringconference.com/2012/PR ESENTA-

TIONS/2011/PDF/05\%20Krishna\%20Srinivansan $\% 20$ and\%20Art\%20Robbins.pdf (accessed on 30.09.2014)

[71] Svensson G., Wood G. - Business ethics in TQM: the qualities and spectrum zones of a case illustration [in] TQM magazine, Vol. 17, No. 1, 2005, pp. 19-34.

[72] Szczepańska K. - Kompleksowe zarzqdzanie jakościa. Przeszłość i teraźniejszość. Oficyna Wydawnicza Politechniki Warszawskiej, Warszawa 2010.

[73] Szekely F., Knirsch M. - Responsible leadership and corporate social responsibility: Metrics for sustainable performance [in] European Management Journal, Vol. 23, No. 6, 2005, pp. 628-647.

[74] Wasilewski L. - Podstawy zarzqdzania jakościa. Wydawnictwo Wyższej Szkoły Przedsiębiorczości i Zarządzania im. L. Koźmińskiego, Warszawa, 1998.

[75] World Commission on Environment and Development, Our common future, 1987.

[76] Zairi M. - Beyond TQM Implementation: The New Paradigm of TQM Sustainabilty [in] Total Quality Management, Vol. 13, No. 8, 2002, pp.1161-1172.

[77] Zimmerman J. B. - EPA's P3 - People, Prosperity, and Planet - Award [in] Sustainability: Science, Practice \& Policy, Vol. 1, No. 2, 2005, pp. 32-33. 